\title{
Sustainable Building Renovation: Proposals for a Research Agenda
}

\author{
Per Anker Jensen * $*$, Esmir Maslesa $@$ and Jakob Brinkø Berg $(\mathbb{D}$ \\ DTU Management Engineering, Technical University of Denmark, 2800 Kgs. Lyngby, Denmark; \\ esmas@dtu.dk (E.M.); jajoh@dtu.dk (J.B.B.) \\ * Correspondence: pank@dtu.dk; Tel.: +45-4525-1674
}

Received: 29 November 2018; Accepted: 6 December 2018; Published: 8 December 2018

check for updates

\begin{abstract}
The purpose of this paper is to identify research gaps and potential new topics for research in relation to the management of sustainable building renovation. The paper is based on a literature review of current research on sustainable building renovation. It analyses the research to pinpoint main focus areas and strengths, as well as identifying areas of weakness and research gaps, which are seen as potential topics for new research. The emphasis is on comprehensive renovation projects of buildings with a holistic sustainability approach. The analysis focuses on the management and process aspects in relation to planning, decision-making, conducting, and evaluating renovation projects. The result is a proposal for new research topics for sustainable building renovation. The current research shows a dominating focus on developing new tools for design support and measuring environmental performance, while there is limited research on developing strategies for renovation and improving the productivity of renovation processes. Out of the three pillars of sustainability, social sustainability is the least defined, and there is a need to develop methods to make a holistic prioritization and evaluation of all aspects of sustainability.
\end{abstract}

Keywords: building renovation; sustainability; management; process; state of the art; research agenda

\section{Introduction}

Renovation of buildings is getting increased attention in many European countries, both in practice and research [1]. A higher level of renovation activities is needed to achieve the environmental targets defined by the European Union (EU), and more research is needed to improve the sustainability of building renovation. The purpose of this paper is to identify research gaps and potential new topics for research in relation to the management of sustainable building renovation, based on a comprehensive, state-of-the-art current research in this field.

The paper takes as its starting point a comprehensive literature review of current research on sustainable building renovation (SBR). The literature review builds on an earlier review done by the same authors for a recent journal paper with the state of SBR [2]. The emphasis is on comprehensive renovation projects of buildings with a holistic sustainability approach covering environmental, social, and economic aspects. The earlier literature review is briefly summarized and supplemented with recent publications in Section 2.

The current research is analysed in Section 3 to pinpoint main focus areas and strengths, as well as identifying areas of weakness and research gaps, which are seen as potential topics for new research. The analysis focuses on the management and process aspects in relation to planning, decision-making, conducting, and evaluating renovation projects.

The result is a proposal for new research topics for SBR, which are discussed and presented in the conclusion of the paper in Section 4. 


\section{Literature Review}

The earlier literature review mentioned in the introduction was related to 10 questions concerning SBR [2]. For the purpose of this paper, the updated literature has been consolidated and organised under six themes. The following presentation of the literature review will only mention some of the most central and mainly the most recent references for each of the themes.

\subsection{Drivers and Barriers}

There is a strong political focus on reaching energy targets on both national, European, and global level, and SBR is an important part of this agenda; at least in Europe. However, energy reduction is seldom the decisive factor behind renovation, except for simple measures with short payback times. Most comprehensive renovation projects are done because an upgrading of the building in a more general sense has become necessary [3]. A European research project concerning SBR investigated the drivers for energy renovation in three European countries-Cyprus, Denmark and Sweden-and the drivers were grouped according to five factors: (1) durability/building physics, (2) economy, (3) environment, (4) comfort, and (5) other. The drivers naturally vary for different types of buildings and organisation in each country [4].

There have been many studies aiming at identifying barriers for SBR, and many proposals to categorise them have been made. Over all, the barriers can simply be divided into two main categories: economic and informational barriers [5]. Lack of the financial incentives and life cycle perspectives are the most significant economic barriers, while too little political consciousness, lack of common direction amongst the main stakeholders, lack of overview, and determining where to prioritise, are the most important informational barriers.

An analysis from Denmark confirmed that building owners and users often have different interests, but this also varies depending on type of buildings. Public schools and listed buildings are usually part of a political agenda, since they get a lot of attention from the general public every day. Energy renovations in social housing in Denmark are highly dependent on external funding and residential democracy. It means that the majority of the residents have to support the idea; otherwise it will not be realised [3].

Principal-agent problems in terms of the landlord/tenant dilemma [6] are present in the building sector in many countries, and is considered to be one of the biggest barriers for energy renovation projects. The landlord provides the tenant with housing, appliances, and installations, and the tenant pays the energy bill. The landlord is therefore not interested in investing too much money in energy efficiency, while the tenant wants to lower the energy costs, and this is where the dilemma occurs. The legislation in this field is very complex, and the maximum rent is regulated by law in some countries, which can be an obstacle for energy renovations, because the maximum possible rent in most cases is insufficient for financing renovation investments.

A recent study presents an overview of barriers, based on 13 literature references, resulting in the following five categories of barriers: (1) institutional and political barriers, (2) market and economic barriers, (3) financial barriers, (4) technical barriers, and (5) behavioural and social barriers [7].

\subsection{Strategies for Renovation}

The focus in most research has so far been on comprehensive renovation projects, concentrating mainly on building envelope and technical installations, which among other things involve a major improvement in energy performance. Such renovations are encouraged in European energy policies and are also called "deep renovations"-for instance, in the EU's Horizon 2020 programme for research and innovation [8]. A main argument for deep renovations is that they are a necessity to achieve radical improvements in energy efficiency.

However, recent research in Sweden has observed a trend of housing associations moving towards applying partial or over-time renovation strategies. The positive side of partial renovations is that it 
can provide opportunities for dealing with social issues, respect for architecture and cultural identity, and limiting the use of resources. They also allow for later inclusion of new technological innovations, and thereby possibly achieving even higher levels of energy efficiency in the long run, while all-at-once deep renovations might lead to lock-ins with the current, less efficient technologies [9].

Comprehensive renovation also almost invariably leads to the occupants being temporarily relocated. In this process, a number of occupants will not return to their renovated place of residence. This can be seen as a way to use renovation to change the occupant population, rather than helping residents [10].

\subsection{Process of Renovation}

In the construction industry, it is often assumed that renovation projects are merely a special type of new construction. They are often organised in the same way, though mostly with a more traditional division of labour and contract forms, and less standardisation. However, there are a number of differences between the process of new building projects and the process of renovation projects. Jensen et al. [11] have identified seven characteristics that distinguish the process of building renovation from the process of new building projects. The most important of these is that in a renovation process there is an existing building and often existing users, and one needs to make a pre-evaluation of the building condition and the experience of using it, which can be a starting point and provide a baseline for a post-evaluation.

The renovation process has been studied in several papers, but mostly in terms of case studies of a limited number of renovation projects, as a basis for developing decision support tools [3,12,13]. Some of these has also made attempts to model the process of renovation $[12,13]$. There are only a few examples of broader cross-sectional research studies-for instance, by use of questionnaire surveys. One example is the study by Gluch et al. [14] mentioned in Section 2.4.

\subsection{Organisation of Renovation}

The typical phases, forms of procurement, and organisation for SBR resembles the traditional situation for new building projects, resulting in high transaction costs. However, there are a number of initiatives to overcome these shortcomings, which can be grouped under the umbrella term "relational contracting", with an emphasis on creating trust and collaborative teams [15]. For the last two decades, sophisticated strategic partnerships have been used in the United Kingdom-often based on the use of framework contracts covering a portfolio of renovation and new building projects. These new forms of collaboration have spread to some other countries, most notably Sweden [16], and more recently to Denmark [17]. The difference between different types of market based and relational contracts are presented in Table 1.

Instigating and participating in such strategic partnerships requires a high level of maturity, and several models have been proposed [17,18]. In Johansen et al. [17], the emphasis is on reflecting both the complex nature of the task, which necessitates a mature organization and the tangible benefits and value that can be expected from making strategic partnerships. The value and complexity are described using key attributes, and they are connected to a five-step maturity model scale, with each step relating to a client-supplier relationship type. The model serves as a guide on how to best choose a relationship type, and where an organization should invest resources in order for them to progress to a more mature client-supplier relationship. The model has also been proposed as a research tool to investigate how strategic partnerships work well or fail to work. 
Table 1. Contract types for building projects (based on [19]).

\begin{tabular}{|c|c|c|c|c|}
\hline & \multicolumn{2}{|c|}{ Market Based Contracts } & \multicolumn{2}{|c|}{ Relational Contracts } \\
\hline & Traditional Tender & Traditional Frame Contract & Project Partnering & Strategic Partnership \\
\hline Selection criteria & Price & $\begin{array}{l}\text { Price + capacity; can include mini-tenders } \\
\text { in case of parallel frame contracts }\end{array}$ & $\begin{array}{l}\text { Best relation between quality and price } \\
++ \text { competences }\end{array}$ & $\begin{array}{l}\text { Best relation between quality and price + } \\
\text { competences + capacity }\end{array}$ \\
\hline Team constellation & Divided in trade groups & $\begin{array}{l}\text { Divided in trade groups with possible } \\
\text { repetition across projects }\end{array}$ & Cross-disciplinary teams in one project & $\begin{array}{c}\text { Cross-disciplinary teams across a number } \\
\text { of projects }\end{array}$ \\
\hline $\begin{array}{l}\text { Possibility to learn } \\
\text { from project to project }\end{array}$ & Limited & Some & Some, but limited due to singular project & $\begin{array}{l}\text { Much knowledge transfer from project } \\
\text { to project }\end{array}$ \\
\hline Communica-tion & $\begin{array}{l}\text { Documentation and } \\
\text { coordination of work }\end{array}$ & Documentation and coordination of work & $\begin{array}{l}\text { Mutual exchange, open } \\
\text { dialogue, workshops }\end{array}$ & $\begin{array}{l}\text { Mutual exchange, open dialogue, } \\
\text { workshops, long-term goals, } \\
\text { common innovation }\end{array}$ \\
\hline Planning & $\begin{array}{l}\text { Within singular projects with } \\
\text { focus on self-interests }\end{array}$ & $\begin{array}{l}\text { Across several project with focus on } \\
\text { self-interests }\end{array}$ & $\begin{array}{l}\text { Within singular projects with focus on } \\
\text { common interests }\end{array}$ & $\begin{array}{l}\text { Across several projects with focus on } \\
\text { common interests }\end{array}$ \\
\hline Client's role & Customer & Multiple customer & Active partner & Active long-term partner \\
\hline
\end{tabular}




\subsection{Decision-Making and Evaluation}

There are many decision support tools, and several systems for sustainability measurements and certifications of buildings. The decision support tools are tools and methods that can help decision-makers, such as professional building owners, to make more informed decisions when dealing with SBR. The decision support tools are mainly used in the early stage of renovation projects (pre-design and design phase), and are primarily focusing on performance estimation, criteria weighting, and design alternatives generation [13]. A study found eight building assessment methods of relevance for the assessment of building renovation [12]. Most of the tools and systems are aimed at decisions and evaluation concerning individual renovation projects. An exception is Nielsen et al. [20], which presents a tool to support decision-making concerning a portfolio of renovation projects.

Environmental targets for SBR aim at reducing resource consumption and negative environmental impacts. A recent study by Zakaria et al. [21] also includes reduction of space requirements and soil sealing, as well as safeguarding the ability to maintain and de-construct buildings.

A systematic literature review on environmental building performance found two basic assessment approaches for measuring environmental building performance. The first approach is based solely on life cycle assessment (LCA), while the second approach encompasses criteria-based certification tools, which in some cases also rely on an LCA approach. The LCA is an internationally acknowledged method for assessing environmental performance of products, including buildings. Amongst the most widespread criteria-based certification, tools are BREEAM from the British Building Research Establishment and LEED from the US Green Building Counsil. A study found that LCA is commonly used in research, but certification tools are more popular among practitioners [22].

Economic targets consider financial parameters like operational cost, rental cost, asset value, and life cycle cost before and after renovation. Zakaria et al. [21] also adds facilitating the most efficient management methods. Payback time is often the most important parameter when considering energy investments, but is a simplified method, while calculations based on life cycle costing (LCC) by the application of net present value can give more precise results [5]. There has recently been an empirical study based on a comprehensive questionnaire survey among real estate and property owners about how LCC is used in practice in Sweden [14]. The authors state that renovation is an area for which LCC is particularly applicable. The study shows a positive attitude towards LCC among real estate and property owners. However, it also reveals simplistic and underdeveloped views on how to use LCC.

There have been attempts to integrate LCC and LCA, but they have not been very successful yet. In Denmark, the State Energy Agency has recently engaged the Danish Building Research Institute to develop tools for both LCC and LCA; however, the tools are neither integrated nor compatible [23].

Social targets are concerned with the supply of adequate buildings for work and life, as well as compliance with health, safety, and security requirements [21]. They can be measured by subjective evaluations in terms of user satisfaction, and objective evaluations in terms of indoor climate and health parameters before and after renovation. Such targets are sometimes called non-energy benefits (NEBs). The social aspect of sustainability is the least developed, as illustrated in Figure 1.

However, there has been an attempt in Sweden to develop social life cycle assessment and to integrate it with LCC and LCA models on an overall level, so that results for LCA, LCA, and social life cycle assessment are shown in the same diagram [24]. Tenant participation in the renovation of housing in marginalized areas has also recently been studied in Sweden by Stenberg et al. [25], and this can also be seen as part of social sustainability. Furthermore, there has recently been a Dutch study on user-focused measurement factors of workspaces for nearly-zero energy office renovations [26], thus combining user satisfaction and low energy consumption in buildings. 


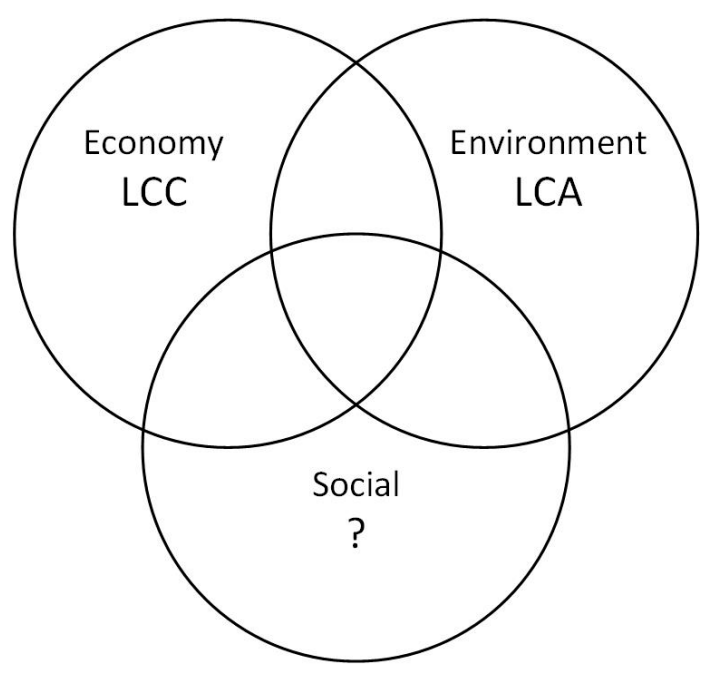

Figure 1. The social dimension is least developed in relation to sustainable building renovation (SBR).

\subsection{Technologies for Renovation}

With regard to technology to be used for SBR, the amount and sophistication of building materials, technical installations, or services have escalated over the past decade [27]. The technological development of new building technologies increases the solution space for SBR and sets requirements for the processes connecting the specific challenges with technological solutions. Fuelled by increasing digitalization, existing and new process technologies promise to help decision makers navigate the complexity and epistemic uncertainty of the specific projects. The reduction of epistemic uncertainty through collection of data for existing buildings has traditionally been supported by "destructive practices". Here, parts of the building are destroyed to uncover important information about the structural principles, thermal bridges, and the current state of building materials, including moisture and mould. However, new technologies have made the collection of data about buildings easier and non-destructive. Such technologies make data collection about existing buildings easier and cheaper. This includes thermal cameras for tracking thermal bridges and insulation patterns, and moisture measurements or indications based on electromagnetic induction methods [28].

New three-dimensional (3D) scanning techniques can create 3D models of existing structures [29]. While these developments currently represent advanced technologies, the current improvement of the sensors and extra cameras in mobile phones suggest that 3D scans in the future might be a feature in our hands [30]. Besides, the general technological development of new building and energy technologies increases the potential solutions for SBR.

\section{Results}

This section is structured with the same subheadings as Section 2. Each subsection includes a short evaluation of the current research presented in the correlated subsection in Section 2 and a proposal of topics for future research.

\subsection{Drivers and Barriers}

The barriers for SBR have been studied broadly, and the drivers for SBR are also quite well researched. The barriers can broadly be divided into economic and informational categories. Among the economic barriers is the landlord/tenants dilemma. Sustainable renovation is mainly initiated because there is an accumulated backlog of maintenance and degraded/outdated building components. Thus, to promote sustainable renovation, including energy improvements, financial incentives are important drivers, but it is important to take various stakeholders' different interests into account, both in relation to the economic and informational barriers. 
There is a need to develop new instruments to increase the volume of SBR, as well as the uptake of new technologies and new forms of organisation of SBR, and to evaluate such instruments. A combination of different types of instruments is needed, including financial incentives and better overview of the options for differentiated stakeholders.

\subsection{Strategies for Renovation}

Research on strategies for SBR is limited, and the political focus on deep renovation has been dominating. There seems to be a trend in some countries towards more stepwise and partial over-time renovation.

There is a need for research on the diversity of current and potential new strategies for SBR of both singular building projects and portfolios of buildings, and how strategies can be prioritised and combined. This strategy development should be able to combine a broad sustainability perspective with the effect of renovation projects on the occupants.

\subsection{Process of Renovation}

There has been some research on the process for SBR, but most of the research has been based on case studies, and dominated by preconceptions of rational decision-making and development of normative guidelines.

There is a need for more in-depth descriptive and cross-sectional studies of SBR processes in practice, to reach a deeper understanding of the different sub-processes of renovation-for instance, the collection of data on buildings before renovation, the actual use of tools in different renovation sub-processes, the characteristics of processes for different building types and organisations, and supporting how renovation really can become more sustainable in a holistic sense.

\subsection{Organisation for Renovation}

The organisation of SBR projects has only been researched to a very limited degree, and there have been limited attempts in practice to develop new forms of organisation of SBR.

There is a need for research that can support increasing the productivity of SBR, for instance by improved collaboration across the value chain, with more learning across projects and companies. The application of more relational contracting seems a promising direction for further development of building renovation.

\subsection{Decision-Making and Evaluation}

There has been intensive research and development of tools and systems to support decision-making and design of SBR projects, but only a few with a focus on portfolios of projects. Following this, there is a need to develop new models for strategic portfolio management of SBR projects. Moreover, the methods for evaluation of social sustainability are underdeveloped, and there is a lack of integration for evaluating the different pillars of sustainability.

There is a need to develop more holistic methods for prioritizing and evaluating SBR. The methods of environmental Life Cycle Assessment (LCA) and economical Life Cycle Costing (LLC) are already well-established and standardised, but they need to be more mutually aligned and integrated, while the social aspects need further elaboration, including social life cycle assessment.

\subsection{Technologies for Renovation}

The current situation with SBR is characterized by a dominating push from technology companies, and this is supported by much technical research. For example, a lot of research is nowadays focusing on 3D modelling, use of augmented and virtual reality, and new data-driven (smart) technologies, while there is lack of focus on actual building users' needs and their current challenges with building performance. 
Thus, there is a need for more research that can support a pull from the demand side in terms of building owners, facilities managers, and users to disclose unfulfilled needs and new opportunities. Also, there is a need for more research on the implementation and (lack of) uptake of new concepts and technologies.

\section{Discussion and Conclusions}

The paper presents a proposal for new research topics for sustainable building renovation. The suggested topics for future research are summarised in Table 2 (without any order of priority).

Table 2. Potential future research topics.

\begin{tabular}{cl}
\hline \multicolumn{1}{c}{ Themes } & \multicolumn{1}{c}{ Research Topics } \\
\hline Drivers and barriers & $\begin{array}{l}\text { Develop new instruments to increase the volume, uptake of new } \\
\text { technologies, and new forms of organisation of SBR, and to evaluate such } \\
\text { instruments. }\end{array}$ \\
\hline Strategies for renovation & $\begin{array}{l}\text { Research on the diversity of current and potential new strategies for SBR } \\
\text { of both singular building projects and portfolios of buildings and how } \\
\text { strategies can be prioritised and combined. }\end{array}$ \\
\hline Process of renovation & $\begin{array}{l}\text { More in-depth descriptive studies of SBR processes in practice, to reach a } \\
\text { deeper understanding of the processes for different building types and } \\
\text { organisations. }\end{array}$ \\
\hline Organisation of renovation & $\begin{array}{l}\text { Research that can support increasing the productivity of SBR, for instance } \\
\text { by improved collaboration across the value chain with more learning } \\
\text { across projects and companies. }\end{array}$ \\
\hline Decision-making and evaluation & $\begin{array}{l}\text { Develop more holistic methods for prioritizing and evaluating SBR. Align } \\
\text { and integrate methods for environmental Life Cycle Assessment (LCA) } \\
\text { and economical Life Cycle Costing (LLC). Further elaboration on the } \\
\text { social aspects of SBR, including social life cycle assessment. }\end{array}$ \\
\hline Technologies for renovation & $\begin{array}{l}\text { Research that can support a pull from the demand side in terms of } \\
\text { building owners, facilities managers and users. Research on the } \\
\text { implementation and (lack of) uptake of new concepts and technologies. }\end{array}$ \\
\hline
\end{tabular}

The current research shows a dominating focus on developing new tools for design support and measuring environmental performance, while there is limited research on developing strategies for renovation and improving the productivity of renovation processes. Out of the three pillars of sustainability, social sustainability is the least defined, and there is a need to develop methods for holistic prioritization and evaluation of all aspects of sustainability.

The research on SBR is dominated by researchers from Northern Europe, and particularly from Sweden. A reason probably is the cold Nordic climate and relatively large social housing sectors. However, the need for SBR is strong in major parts of Europe and the world. Thus, there is a clear need to increase and broaden the research on SBR, if the European and global targets to reduce energy consumption and limit climate change are going to be fulfilled.

Author Contributions: Conceptualization, P.A.J.; methodology, P.A.J.; formal analysis, P.A.J., E.M., and J.B.B.; investigation, P.A.J., E.M., and J.B.B.; writing-original draft preparation, P.A.J.; writing-review and editing, P.A.J., E.M. and J.B.B.; visualization, J.B.B.; supervision, P.A.J.; project administration, P.A.J.; funding acquisition, P.A.J. and E.M.

Funding: This research was partly funded by Innovation Fund Denmark.

Conflicts of Interest: The authors declare no conflict of interest. 


\section{References}

1. BPIE. Europe's Buildings under the Microscope: A Country-by-Country Review of the Energy Performance of Buildings; Building Performance Institute Europe: Brussels, Belgium, 2011.

2. Jensen, P.A.; Maslesa, E.; Berg, J.B.; Thuesen, C. 10 questions concerning sustainable building renovation. Build. Environ. 2018, 143, 130-137. [CrossRef]

3. Jensen, P.A.; Maslesa, E. Value Based Renovation-A Tool for Decision-making and evaluation. Build. Environ. 2015, 92, 1-9. [CrossRef]

4. Gohardani, N.; Björk, F.; Jensen, P.A.; Maslesa, E.; Kanarachos, S.; Fokaides, P.A. On Stakeholders and the Decision Making Process Concerning Sustainable Renovation and Refurbishment in Sweden, Denmark and Cyprus. Archit. Environ. 2013, 1, 21-28. [CrossRef]

5. Jensen, P.A.; Maslesa, E.; Gohardani, N.; Björk, F.; Kanarachos, S.; Fokaides, P.A. Sustainability Evaluation of Retrofitting and Renovation of Buildings in Early Stages. In Proceedings of the 7th Nordic Conference on Construction Economics and Organisation, Trondheim, Norway, 12-14 June 2013.

6. Ástmarsson, B.; Jensen, P.A.; Maslesa, E. Sustainable Renovation of Residential Buildings and the Landlord/Tenant Dilemma. Energy Policy 2013, 63, 355-362. [CrossRef]

7. Meijer, F.; Straub, A.; Mlecnik, E. Consultancy centres and pop-ups as local authority policy instruments to stimulate adoption of energy efficiency by homeowners. Sustainability 2018, 10, 2734. [CrossRef]

8. EU. Horizon 2020—Work Programme 2016 -2017; EU: Brussels, Belgium, 2016.

9. Femenías, P.; Mjörnel, K.; Thuvander, L. Rethinking deep renovation: The perspective of rental housing in Sweden. J. Clean. Prod. 2018, 195, 1457-1467. [CrossRef]

10. Baeten, G.; Westin, S.; Pull, E.; Molina, I. Pressure and violence: Housing renovation and displacement in Sweden. Environ. Plan. A Econ. Space 2016, 49, 631-651. [CrossRef]

11. Jensen, P.A.; Johansen, J.B.; Thuesen, C. Prerequisites for Successful Strategic Partnerships for Sustainable Building Renovation. In Proceedings of the 9th Nordic Conference on Construction Economics and Organisation (CEO 2017), Chalmers University of Technology, Gothenburg, Sweden, 13-14 June 2017.

12. Thuvander, L.; Femenías, P.; Mjörnell, K.; Meiling, P. Unveiling the Process of Sustainable Renovation. Sustainability 2012, 4, 1188-1213. [CrossRef]

13. Nielsen, A.N.; Jensen, R.L.; Larsen, T.S.; Nissen, S.B. Early stage decision support for sustainable building renovation-A review. Build. Environ. 2016, 103, 165-181. [CrossRef]

14. Gluch, P.; Gustafsson, M.; Baumann, H.; Lindahl, G. From Tool-making to Tool-using-And back: Rationales for Adoption and Use of LCC. Int. J. Strat. Prop. Manag. 2018, 22, 179-190. [CrossRef]

15. Kumaraswamy, M.M.; Rahman, M.M.; Ling, F.E.; Phng, S.T. Reconstructing Cultures for Relational Contracting. J. Constr. Eng. Manag. 2005, 131, 1065-1075. [CrossRef]

16. Kadefors, A.; Thomassen, M.A.; Jørgensen, M.N. Long Term Strategic Collaboration in the Construction Industry -Case Studies from Denmark and Sweden. A Pre-Study; Realdania: Copenhagen, Denmark, 2013.

17. Johansen, J.B.; Jensen, P.A.; Thuesen, C. Maturity Model for Strategic Collaboration in Sustainable Building. In Proceedings of the ARCOM Conference, Cambridge, UK, 4-6 September 2017; pp. 259-268.

18. Meng, X.; Sun, M.; Jones, J. Maturity Model for Supply Chain Relationships in Construction. J. Manag. Eng. 2011, 27, 97-105. [CrossRef]

19. Berg, J.B. Mindre Værditab i Renoveringsprocessen-Potentialer ved Strategiske Partnerskaber Los Loss of Value in the Renovation Process_Potentials of Strategic Partnerships; Booklet; REBUS: Taastrup, Denmark, 2018; Available online: www.rebus.nu (accessed on 30 November 2018).

20. Nielsen, A.N.; Larsen, T.S.; Nissen, S.B.; Jensen, R.L. REDIS: A value-based decision support tool for renovation of building portfolios. Build. Environ. 2018, 142, 107-118.

21. Zakaria, I.B.; Hashim, S.Z.; Ahzahar, N. Critical Success Factor for Sustainable Facilities Management: A Review of Literature. Int. J. Acad. Res. Bus. Soc. Sci. 2018, 8, 469-480.

22. Maslesa, E.; Jensen, P.A.; Birkved, M. Indicators for quantifying environmental building performance: A systematic literature review. J. Build. Eng. 2018, 19, 552-560. [CrossRef]

23. Bauerova, M. Evaluation of Deep Renovation of an Existing Mixed-Use Building Versus Its Demolition and Replacement with a New Building. Master's Thesis, Technical University of Denmark, Lyngby, Denmark, 2017. 
24. Mjörnell, K.; Bass, A.; Lindahl, M.; Molnar, S. A Tool to Evaluate Different Renovation Altenatives with Regard to Sustainability. Sustainability 2014, 6, 4227-4245. [CrossRef]

25. Stenberg, J. Dilemmas associated with tenant participation in renovation of housing in marginalized areas may lead to system change. Cogent Soc. Sci. 2018, 4, 1-22. [CrossRef]

26. Kwon, M.; Remøy, H.; Van den Dobbelsteen, A.; Knaack, U. User-focused Measurement Factors of Workspace for Nearly Zero Energy Office Renovation: Findings from Literature Review. In Proceedings of the ERES Conference, Delft University of Technology, Delft, The Netherlands, 28 June-1 July 2017.

27. Ma, Z.; Cooper, P.; Daly, D.; Ledo, L. Existing building retrofits: Methodology and state-of-the-art. Energy Build. 2012, 55, 889-902. [CrossRef]

28. Hola, J.; Schabowicz, K. State-of-the-Art Non-Destructive Methods for Diagnostic Testing of Building Structures-Anticipated Development Trends. Arch. Civ. Mech. Eng. 2010, 10, 5-18. [CrossRef]

29. Lehtola, V.V.; Kaartinen, H.; Nüchter, A.; Kaijaluoto, R.; Kukko, A.; Litkey, P.; Honkavaara, E.; Rosnell, T.; Vaaja, M.T.; Virtanen, J.P.; et al. Comparison of the selected state-of-the-art 3D indoor scanning and point cloud generation methods. Remote Sens. 2017, 9, 796. [CrossRef]

30. Schöps, T.; Sattler, T.; Häne, C.; Pollefeys, M. Large-scale outdoor 3D reconstruction on a mobile device. Comput. Vis. Image Underst. 2017, 157, 151-166. [CrossRef]

(c) 2018 by the authors. Licensee MDPI, Basel, Switzerland. This article is an open access article distributed under the terms and conditions of the Creative Commons Attribution (CC BY) license (http:/ / creativecommons.org/licenses/by/4.0/). 